\title{
Syberyjska saga rodziny Kuleszów - wywiad z Anną Domaradzką \\ Przeprowadzil, opatrzył wstępem i opracował Mariusz Puchacz
}

W ostatnich dekadach XIX w. rozpoczęła się masowa emigracja zarobkowa z ziem polskich. Polacy emigrowali przede wszystkim do Ameryki Południowej i Północnej, a w szczególności - do dynamicznie rozwijających się Stanów Zjednoczonych. Często nie pamięta się jednak o tym, że nie brakowało i tych, którzy poprawę swojej sytuacji finansowej upatrywali w wyjeździe w głąb Rosji, w tym, na kojarzącą się głównie z miejscem zsyłek, Syberię ${ }^{1}$. Dom, jakim Syberia stała się dla tysięcy Polaków, w następstwie rewolucji bolszewickiej $1917 \mathrm{r}$. i krwawej wojny domowej zamienił się w swego rodzaju pułapkę. Z tym okresem w dziejach polskiej diaspory na Syberii i Dalekim Wschodzie związana jest ewakuacja i repatriacja polskich dzieci: sierot, półsierot, bezdomnych i tych w trudnym położeniu materialnym. Została ona zorganizowana przez Polski Komitet Ratunkowy utworzony jesienią 1919 r. we Władywostoku przez tamtejsze polskie organizacje. Na jego czele stanęli Anna Bielkiewicz, Józef Jakóbkiewicz i Wieńczysław Piotrowski. W latach 1920-1923, dzięki konsekwentnej pracy tych osób, jak i wielu ich współpracowników, ewakuowano z Syberii i Dalekiego Wschodu i przewieziono do Polski w trzech transportach blisko 900 dzieci. Pierwsza grupa, ewakuowana z Rosji w 1920 r., przez Japonię i Stany Zjednoczone dotarła do kraju w marcu 1922 r. Druga - została przewieziona drogą morską bezpośrednio z Japonii do Polski latem 1922 r. Ostatnia i zarazem najmniejsza grupa dzieci, została przewieziona do kraju koleją, dzięki pomocy władz sowieckich w styczniu 1923 r. $^{2}$ Przeprowadzenie tej zakrojonej na szeroką skalę akcji

\footnotetext{
1 Do wybuchu I wojny światowej na Syberię przyjechało kilkadziesiąt tysięcy Polaków: osób wykształconych (dla których możliwość rozwoju zawodowego i finansowego była na ziemiach polskich zamknięta), robotników, górników oraz rolników. S. Leończyk, Polskie osadnictwo wiejskie na Syberii w drugiej połowie XIX i na początku XX wieku, Warszawa 2017; Z. Łukawski, Ludność polska w Rosji 1863-1914, Wrocław-Warszawa-Kraków-Gdańsk 1978, rozdz. III.

2 Zagadnienie to jest znane dzięki pracy badaczy polskich i japońskich, w szczególności Wiesława Theissa. Zob. W. Theiss, Dzieci Syberyjskie: dzieje polskich dzieci repatriowanych z Syberii i Mandżurii w latach 1919-1923, Waszawa 1991; W. Theiss, T. Matsumoto, Dzieci Syberyjskie: pomoc Japonii dla dzieci polskich z Syberii, 1919-1922, Warszawa 2009.
} 
nie byłoby możliwe bez wsparcia wielu osób i instytucji, w szczególności zaś państwa japońskiego, Japońskiego Czerwonego Krzyża i Polonii amerykańskiej.

Zamieszczony poniżej wywiad z Panią Anną Domaradzką (z domu Kulesza) - wnuczką osadnika z Syberii i córką repatriowanego „dziecka syberyjskiego” jest świadectwem burzliwych polskich dziejów. Losy jej rodziny jak w soczewce ukazują wiele wydarzeń polskiej historii: masową emigrację zarobkową, zmagania z sowiecką Rosją, pomoc okazywaną rodakom przez amerykańską Polonię, życzliwy stosunek państwa japońskiego wobec niepodległej Polski czy trud codziennego życia w II Rzeczpospolitej.

Mariusz Puchacz

Wywiad został przeprowadzony 17 czerwca 2018 r. w Białymstoku

Mariusz Puchacz (M.P.): Kiedy Pani przodkowie osiedlili się na Syberii?

Anna Domaradzka (A.D.): Moja rodzina pochodzi z Podlasia. Była to wielodzietna rodzina, w której najstarsze dziecko zostawało na gospodarstwie, w domu, pozostałe musiały szukać pracy. W ostatniej dekadzie XIX w. rozpoczęła się budowa Kolei Transsyberyjskiej, co sprawiło, że wzrosło zapotrzebowanie na pracowników³. Mój dziadek, Aleksander Kulesza i jego brat Antoni, zdecydowali się skorzystać z tej możliwości i pojechali na wschód. Dziadek urodzony w 1876 r. podjął taką decyzję w wieku 20 lat. Najpierw pracował przy budowie odcinka Kolei Transsyberyjskiej w okolicach Czyty ${ }^{4}$, potem Harbina ${ }^{5}$ i dalej pojechał w stronę Błagowieszczeńska ${ }^{6}$. Dziadek zaczął pracę jako płatniczy na kolei, rozwoził pieniądze pomiędzy stacjami i wypłacał je pracownikom poszczególnych odcinków budowy. Był to dobry początek. Nie był to człowiek, który budował kolej, tylko pracował w usługach. Uzyskanie stałego dochodu

\footnotetext{
3 Budowę Kolei Transsyberyjskiej rozpoczęto w 1891 r. Miała ona połączyć europejską część Imperium Rosyjskiego z Dalekim Wschodem. Trasa wiodła do Władywostoku. Przy jej budowie pracowały setki polskich inżynierów, techników i robotników, w szczytowym momencie stanowiących ok. 18-20\% wszystkich pracowników. Z. Łukawski, op. cit., s. 68-69. Zob. także: Z. Lech, Syberia Polska pachnaca, Warszawa 2002, rozdz. 9; B. Orłowski, O polskim wkładzie w budowe Wielkiej Kolei Transsyberyjskiej, [w:] Polacy w nauce, gospodarce i administracji na Syberii w XIX i na początku XX wieku, red. A. Kuczyński, Wrocław 2007, s. 413-428.

4 Stolica obwodu zabajkalskiego, obecnie stolica Kraju Zabajkalskiego.

5 Harbin jest miastem ,założonym” przez polskiego inżyniera Adama Szydłowskiego w 1898 r. Znajduje się on na terenie północnych Chin, przez które na mocy układu rosyjsko-chińskiego z 1896 r. przechodziła kolej wschodniochińska. Dzięki temu skrótowi trasa Kolei Transsyberyjskiej była krótsza o prawie 900 kilometrów. Z. Lech, op. cit., s. 229-231.

6 Wówczas i obecnie stolica obwodu amurskiego. Błagowieszczeńsk nie leży na trasie głównej linii Kolei Transsyberyjskiej, lecz ok. $100 \mathrm{~km}$ na południe od niej. Jest z nią połączony odnogą kolejową, której budowa została zakończona w trakcie I wojny światowej.
} 


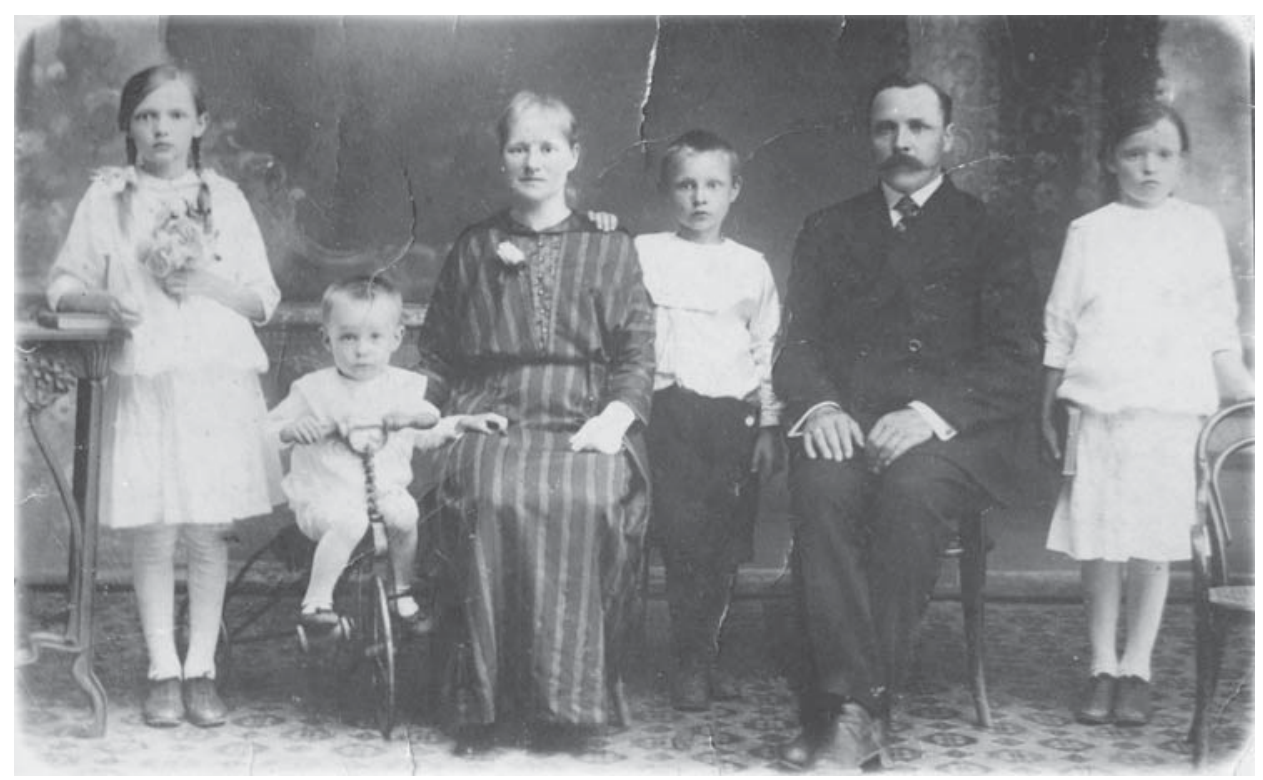

Rodzina Kuleszów, Syberia, ok. 1914 r. Kolejno od lewej: Czesława Lucja, Stanisław, Marcjanna (z d. Jabłońska), Leopold, Aleksander, Felicja. Zbiory rodzinne A. Domaradzkiej

umożliwiło mu poślubienie Marcjanny Jabłońskiej, pochodzącej z tych samych okolic Podlasia. Pobrali się gdzieś na trasie budowy Kolei Transsyberyjskiej, nie wiem dokładnie gdzie. Po ślubie urodziła się im czwórka dzieci, najstarsza córka, Łucja Czesława w 1904 r., druga córka Felicja w 1906, mój ojciec Leopold w 1908. Ta trójka dzieci miała zapisane w metrykach jako miejsce urodzenia stację Buchedu, niedaleko Harbina. Czwarte dziecko, Stanisław, urodziło się w 1913 r. w miejscowości Artieuszka, niedaleko Czyty. Co ciekawe, starsza córka została ochrzczona w Czycie, a mój ojciec w Harbinie. To są bardzo duże odległości pomiędzy tymi miastami, ale prawdopodobnie chrzest $w$ innych parafiach kościelnych i w innych miejscowościach związany był z przemieszczaniem się budowy kolei na wschód. Po kilku latach pracy na kolei, w 1913 r. dziadek zdecydował, że przeniesie się z całą rodziną na północ do Błagowieszczeńska, gdzie osiedlą się prawdopodobnie na dłużej.

\section{M.P.: Jak wyglądało życie Pani rodziny w Błagowieszczeńsku?}

A.D.: Dzieci chodziły do szkoły. Najpierw starsza ciotka uczęszczała do regularnej rosyjskiej szkoły podstawowej, a potem też młodsza i wreszcie mój ojciec. Starsza ciotka skończyła w Błagowieszczeńsku szkołę podstawową i cztery klasy szkoły średniej. Mój ojciec zaczął tam tylko szkołę podstawową, była to szkoła imienia Gogola, ale zdążył skończyć tylko trzy klasy, zanim zaczął się trudny okres zawieruchy rewolucyjnej i wojny domowej. 


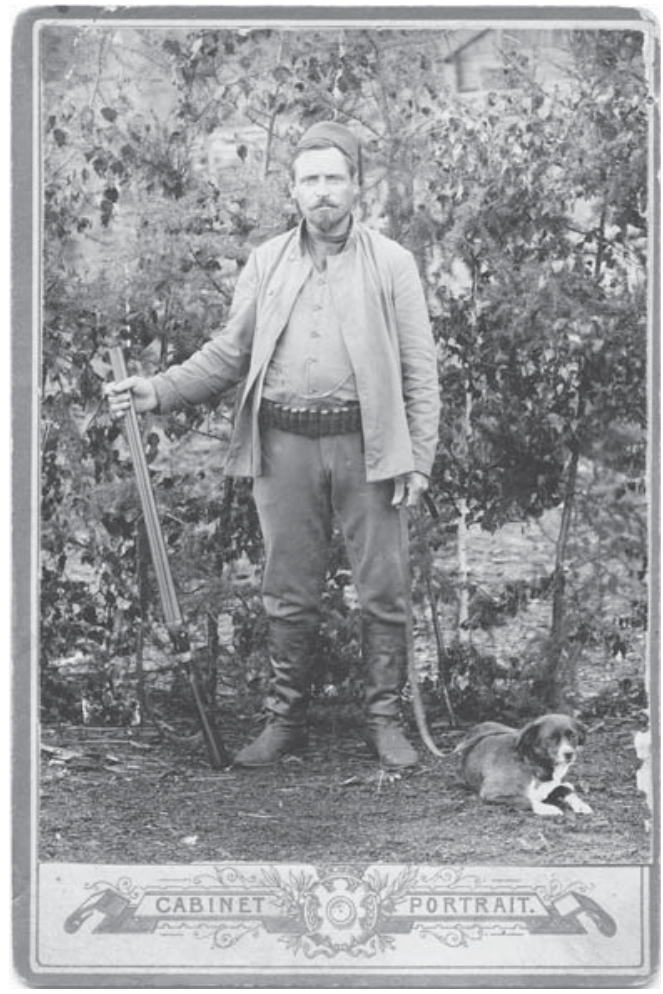

Włoski myśliwy Antonio Paskualini. Zbiory rodzinne A. Domaradzkiej

W Błagowieszczeńsku dziadek z babcią otworzyli jadłodajnię dla lokalnej ludności i pracowników budujących kolej. Raczej powodziło im się zupełnie dobrze. Tak jak ojciec opowiadał, zatrudniali dwóch myśliwych, którzy chodzili do tajgi polować na zwierzynę, taką jak kozły, dziki, sarny czy jelenie. Myśliwi ci byli Włochami, w zbiorach rodzinnych zachowało się zdjęcie jednego z nich. Dwa razy w tygodniu wychodzili do tajgi i przynosili świeżo upolowaną zwierzynę. Dziadek z babcią mieli takie olbrzymie drewniane beczki, w których solili i przyprawiali to mięso, aby móc je dłużej przechować. Zapotrzebowanie na nie było duże, ponieważ był to podstawowy produkt wyżywienia w czasie długich syberyjskich zim.

Babcia mając czwórkę dzieci w pewnym momencie zdecydowała, że potrzebują pomocy. Było dla niej już za trudno jednocześnie przygotowywać posiłki w stołówce, prowadzić księgowość oraz zajmować się dziećmi i domem. Ściągnęła z Podlasia swoją siostrę - Władysławę Jabłońską, która zajęła się przede wszystkim prowadzeniem księgowości. Z opowieści rodzinnych pamiętam, że to przedsięwzięcie rodzinne prosperowało zupełnie dobrze, także pod względem finansowym. Po pewnym czasie dziadek dostał stałą pracę w lokalnym państwo- 
wym banku w Błagowieszczeńsku. Został tam zatrudniony jako buchalter, było to zdecydowanie korzystniejsze dla całej rodziny. Babcia już wtedy nie musiała pracować; mogła zająć się tylko wychowaniem dzieci i domem. Stała praca dziadka dawała regularny dochód i pozwalała im prowadzić całkiem dostatnie życie. Wydaje mi się, patrząc na ocalałe rodzinne zdjęcia z tego okresu, że powodziło im się w miarę dobrze, wszyscy byli raczej zadbani, dobrze ubrani, a starannie gromadzone oszczędności finansowe rosły. Lepsza i ciekawa przyszłość była przed nimi, ale nadszedł rok 1917 i burzliwe lata rewolucji.

M.P.: W jaki sposób rewolucja zmieniła dotąd ustabilizowane i dostatnie życie Pani rodziny?

A.D.: Moja rodzina była aktywna w Domu Polskim? . Była to instytucja skupiająca lokalną Polonię, dzieci uczyły się tam języka polskiego, dodatkowo oprócz zajęć w regularnych rosyjskich szkołach. Polacy w Błagowieszczeńsku tworzyli zwartą kolonię, to byli ludzie zaprzyjaźnieni, którzy pielęgnowali polską

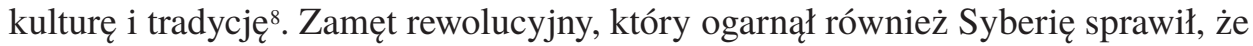
zaczęli myśleć o powrocie do ziemi ojczystej. Polacy, skupieni wokół Domu Polskiego postanowili napisać list do Polski, tak jak mi ojciec opowiadał, do Józefa Piłsudskiego. Mieli w nim opisać tragiczną sytuację kolonii polskiej w Błagowieszczeńsku i straszną rzeczywistość rewolucji w tej okolicy. Znaleźli łącznika, który miał przewieźć list do Warszawy. W okolicy Błagowieszczeńska płynie rzeka Amur ${ }^{9}$, która w tym miejscu ma ok. 3 kilometrów szerokości. Przedostający się przez tę rzekę wysłannik został złapany przez bolszewików. W konsekwencji służby sowieckie rozpoczęły poszukiwania osób, które podpisały się pod tym listem. Było ich ok. 20. Ksiądz Kamiński ${ }^{10}$, prowadzący tam polską parafię, został wezwany przez bolszewików, którzy powiedzieli mu, że jeśli zgodzi się na potwierdzenie nazwisk z tej listy, nie poniesie żadnych konsekwencji. Po kilku dniach ksiądz Kamiński zgodził się. Kiedy tylko potwierdził, że był współautorem listu i tożsamość pozostałych osób, które złożyły podpis pod pismem do Piłsudskiego, pierwszą rzeczą, jaką zrobili bolszewicy było aresztowanie księdza Kamińskiego i zorganizowanie procesu pokazowego dla wszystkich Polaków, których nazwiska były na tej liście. Wyroki były od kilku do kilkunastu

\footnotetext{
7 Domy Polskie, czyli instytucje kulturalno-oświatowe, zaczęły powstawać w Rosji dopiero po rewolucji 1905 r. Pierwszy powstał w Odessie, a kolejne w następnych latach na obszarze całego państwa, od Petersburga do Władywostoku. Zob. Z. Łukawski, op. cit., s. 146 i n.

8 Społeczność polska w Błagowieszczeńsku była stosunkowo liczna. W 1914 r. liczyła ok. 1000 osób. M. Kałuski, Polacy w rosyjskiej Mandżurii, „Studia Polonijne” 2001, t. 22, s. 135.

9 Amur jest rzeką graniczną, po jej południowej stronie znajdują się Chiny.

10 Ks. Władysław Kamiński, ur. w 1863, zm. w 1950 r. w Łabuniach koło Zamościa. Ukończył seminarium metropolitalne w Petersburgu, w 1892 r. przyjął święcenia kapłańskie. Wikariusz parafii w Tobolsku i Krasnojarsku w latach 1896-1898, następnie przez 20 lat proboszcz parafii w Czycie, skąd w 1917 r. trafił do parafii Przemienienia Pańskiego w Błagowieszczeńsku. A. Kijas, Polacy w Rosji od XVII wieku do 1917 r. Stownik biograficzny, Warszawa-Poznań 2000, s. 144.
} 
lat. Mój dziadek został skazany, tak jak mówił ojciec, na 8 lat więzienia ${ }^{11}$. I tak skończyła się dobra passa mojej rodziny. Dziadek w więzieniu, czwórka małych dzieci, a babcia bez możliwości ich utrzymania i wyżywienia, w skrajnej biedzie.

M.P.: W szczególnie trudnym położeniu znalazły się dzieci. Ich ratowaniem zajął się Polski Komitet Ratunkowy, którego przedstawiciele Wieńczysław i Władysław Piotrowscy, jesienią 1920 r. przybyli do Błagowieszczeńska. Pani dziadkowie zdecydowali się przekazać im swoje dzieci.

A.D.: To znaczy nie wszystkie dzieci. Tak jak mówiłam, dziadek był w więzieniu, babcia została sama $\mathrm{w}$ bardzo trudnym położeniu materialnym, w czasie rewolucji, gdy nie ma szacunku dla życia ludzkiego, a każdy człowiek, który pojawia się na horyzoncie może być wrogiem. Jak utrzymać czwórkę małych dzieci, skąd wziąć żywność, jak ubrać te dzieci, jak dać im możliwość przeżycia?

Dziadek z babcią otrzymali informację o przyjeździe do Błagowieszczeńska braci Piotrowskich z Polskiego Komitetu Ratunkowego we Władywostoku, prawdopodobnie z Domu Polskiego albo z polskiego kościoła. Wśród Polaków rozeszła się pogłoska, że można wysłać dzieci do Polski. Dziadkowie zdecydowali, że wyślą swoje dzieci, skorzystają z oferty, bo to jest prawdopodobnie jedyna szansa, żeby one przeżyły. Ale, co ciekawe, postanawiają wysłać tylko trójkę starszych dzieci, zostawiając najmłodsze dziecko z babcią. Ja teraz jako matka, widze jak nieprawdopodobnie trudna i odważna musiała być ta decyzja. Podzielić rodzinę, wysłać starsze rodzeństwo w nieznane i tygodniami, miesiącami nie wiedzieć co się z nimi dzieje. Jest obietnica, jest perspektywa, że dzieci przeżyją, ale nie wiem, czy oni tak faktycznie wierzyli, że to przedsięwzięcie wysłania dzieci do Polski przez Japonię i Stany Zjednoczone powiedzie się. Być może potrzebowali jakiejś ,,asekuracji”, dlatego tak na wszelki wypadek zostawili najmłodsze dziecko przy sobie, że jak ta akcja przesłania starszych dzieci do ojczyzny drogą dookoła świata nie wyjdzie, to może chociaż to najmłodsze przeżyje. Pomimo tego, że dziadek był ciągle w więzieniu, a babcia bez środków do życia, musieli przecież myśleć o lepszej przyszłości, chociażby dla dzieci. Tak jak mi później opowiadał już prawie osiemdziesięcioletni stryjek, właśnie ten mały wtedy chłopczyk, babcia musiała nawet żebrać, prosiła Rosjanki o pomoc. Okazuje się, że indywidualnie one bardzo babci pomogły, dawały żywność, jakieś ubrania, być może nawet schronienie i to wystarczyło na przetrwanie.

11 Tu zachodzi niezgodność, ponieważ według dokumentów urzędu zajmującego się wymianą więźniów politycznych Aleksander Kulesza został skazany na 6 lat więzienia ,,jako członek domu Polskiego w Błagowieszczeńsku za kontrrewolucję i działalność kulturalną w duchu narodowym Polskim". Zob. Personalja osób przeznaczonych przez Delegację Polska do Spraw Repatrjacji do wymiany personalnej z Rosji, załącznik do Pisma Mosdelpolu do Wardelpolu w sprawie zweryfikowanej listy „208” wymiany personalnej, 12 IX 1924, [w:] Wymiana więźniów politycznych pomiędzy II Rzeczpospolita a Sowietami w okresie międzywojennym. Dokumenty i materiaty, oprac. W. Materski, Warszawa 2000, s. 183. Ksiądz Kamiński również został skazany na 6 lat więzienia, ibidem, s. 181. 
I co jest niesłychane i zdumiewające to fakt, że dziadek wtedy otrzymał przepustkę z więzienia na przewiezienie dzieci do Władywostoku. I tak jak mój ojciec mówił, z obstawą, całą rodziną wraz z Wieńczysławem Piotrowskim i zebranymi przez niego innymi polskimi dziećmi pojechali pociągiem do Władywostoku, żeby wysłać starsze dzieci do Polski. Była to bardzo długa droga koleją, licząca tysiące wiorst ${ }^{12}$. Najpierw pojechali do Chabarowska, a z Chabarowska do Władywostoku ${ }^{13}$. Brat dziadka Antoni, który w tym czasie pracował w straży pożarnej w Szanghaju, powiadomiony o zamiarze wysyłki dzieci do Polski, przyjechał do Władywostoku, żeby spotkać się z rodziną. Wszyscy odnaleźli się na stacji Arteanskaja na przedmieściach Władywostoku. Był to taki rodzaj rodzinnego wsparcia i pomocy w tej, jakże trudnej emocjonalnie sytuacji. Tak jak ojciec później opowiadał, babcia ciągle płakała i płakała, bała się o przyszłość starszych dzieci wysyłanych w nieznane. Ten ból rozstania matki z dziećmi niewątpliwie był okrutny, trudny do pokonania. Było to też ostatnie spotkanie mego dziadka z jego bratem. Po przekazaniu dzieci na statek do Japonii wuj Antoni wrócił do Szanghaju, potem wszelki kontakt z nim już się urwał, zanikł. Natomiast mój dziadek wrócił do więzienia do Błagowieszczeńska.

Ojciec i jego siostry zostały przyjęte przez Polski Komitet Ratunkowy, choć tak jak później opowiadała ciotka Czesława Łucja, nie była wtedy pewna czy z powodu jej wieku nie zostanie odrzucona, miała wówczas 16 lat. Była jednym z najstarszych dzieci wysłanych do Polski ${ }^{14}$.

\section{M.P.: Kiedy Pani ojciec i ciotki opuścili Rosję?}

A.D.: W grudniu 1920 r. razem z innymi polskimi dziećmi z Syberii przepłynęli statkiem z Władywostoku do portu Tsuruga w Japonii. Tam, na kilka godzin trafili do lokalnej szkoły. Kilka lat temu odwiedziłam ten port i miasto Tsuruga, ta szkoła ciągle tam istnieje. Jeden z jej wychowanków pokazał mi

121 wiorsta $=1066,79$ metrów.

13 Piotrowski wspominał o tym w następujący sposób: „wreszcie 10 grudnia przeprowadzani przez p.p. Pokorskich, Rybaka, Jackowskich, Kuleszów i innych ruszyliśmy z westchnieniem ulgi do Chabarowska". W. Lazęga [Piotrowski], Sprawozdanie z wędrówki odbytej w sprawie ratownictwa dzieci polskich do kraju amurskiego, „Przegląd” [Harbin] 1921, nr 40, s. 7 (jest to druga część sprawozdania, pierwsza została opublikowana w numerze 39). Błagowieszczeńsk opuściło z Piotrowskim 21 dzieci. Do Władywostoku dotarli 30 grudnia.

14 Przyjęcie przez PKR osoby w tym wieku i wysłanie jej do Stanów Zjednoczonych było możliwe dzięki porozumieniu wypracowanemu w drugiej połowie listopada 1920 r. przez Jakóbkiewicza z organizacją finansującą transport i pobyt dzieci w USA, Wydziałem Narodowym Polskim (WNP). Zgodnie z nim Bielkiewiczowa mogła przysłać do USA dzieci ,niezależnie od wieku”. Telegram, Jakóbkiewicz i Smulski do Bielkiewicz, 24 XI 1920, Muzeum Polskie w Ameryce (MPA), WNP, sygn. 205. Przed osiągnięciem tego konsensusu WNP protestował przeciwko przysyłaniu młodzieży, przypominając, że ,prosiliśmy D-ra Jakóbkiewicza, aby dzieci starszych niż 12, a co najwyżej 14 lat tu nie przysyłano". Wilde do Lubomirskiego, 4 XI 1920, MPA, WNP, sygn. 205; także: Smulski do Targowskiego, 25 X 1920, ibidem; Wilde do Jakóbkiewicza, 26 X 1920, ibidem; WNP do Targowskiego, 27 X 1920, ibidem. 


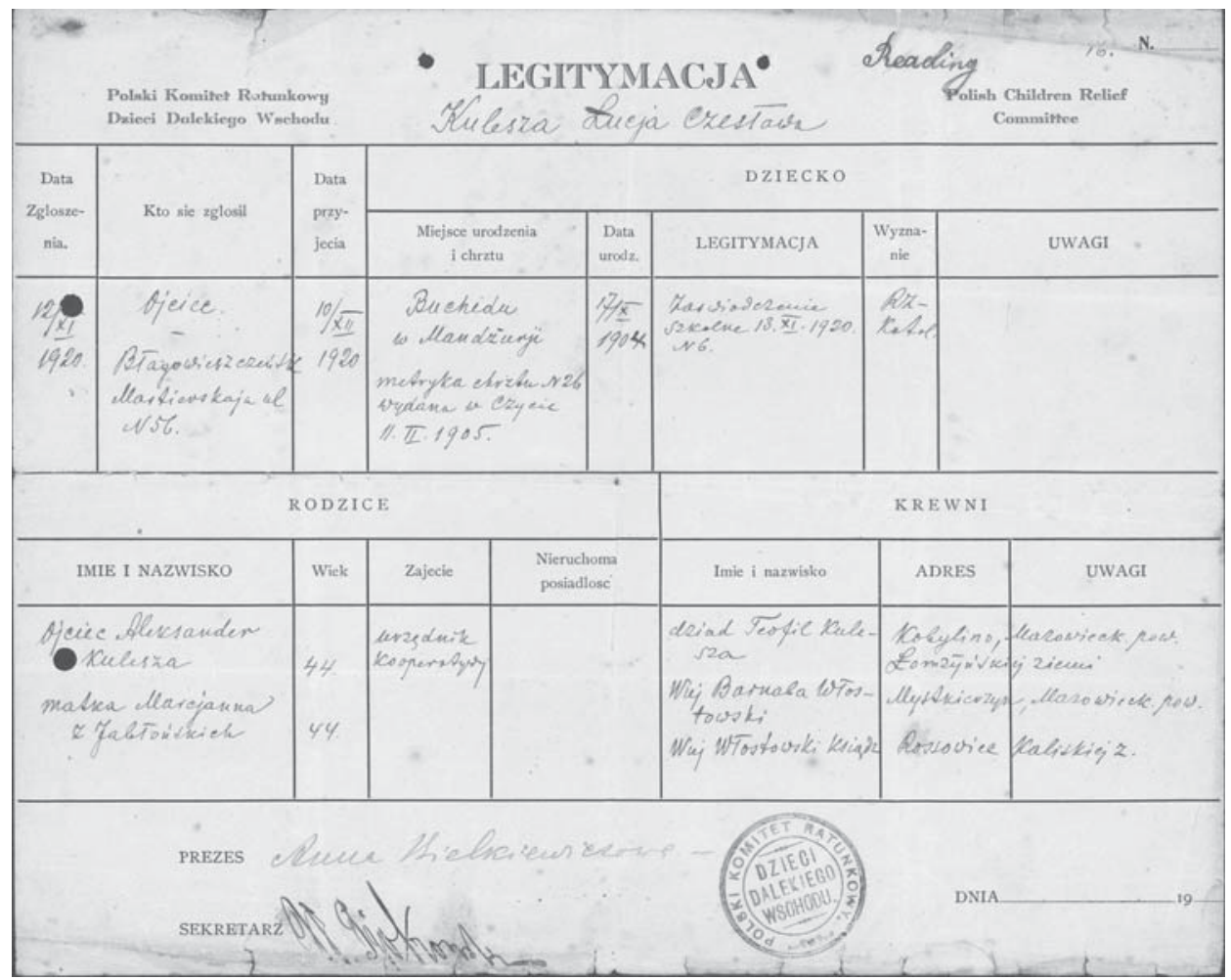

Legitymacja potwierdzająca przyjęcie Łucji Czesławy Kuleszy przez Polski Komitet Ratunkowy. Zbiory rodzinne A. Domaradzkiej

nawet budynek szkoły i powiedział, że ciągle w jej historii przypomina się, że uczestniczyli $\mathrm{w}$ akcji pomocy polskim dzieciom ${ }^{15}$. Z Tsurugi pociągiem dzieci przewieziono do Tokio. Zarówno w Tsurudze, jak i potem w Tokio, Japończycy zajęli się polskimi dziećmi bardzo życzliwie i serdecznie. Mój ojciec i jego siostry miały rodziców, jednak większość dzieci to były sieroty lub półsieroty, często chore, obdarte, głodne, niedożywione, zaniedbane, a nawet zawszone. Ewakuacja z Dalekiego Wschodu stwarzała tym dzieciom szansę na uratowanie i lepsze życie. Japończycy zajmowali się nimi bardzo dokładnie, dzieci musiały najpierw przejść kwarantannę i ze względów sanitarnych zostały pozbawione wszystkich swoich rzeczy. Japończycy przygotowali dla nich nowe, czyste ubrania, zabawki i słodycze.

15 W muzeum w Tsurudze znajduje się stała wystawa poświęcona ewakuacji polskich dzieci z Syberii i Mandżurii. Jest ona dostępna również w wersji internetowej: http://www.tmo-tsuruga.com/ kk-museum/index_e.html. 


\section{M.P.: Jak pobyt w Japonii został zapamiętany przez Pani ojca?}

A.D.: Po przyjeździe do Tokio, tak jak ojciec opowiadał, posadzono wszystkie dzieci przy takich maleńkich, niskich stoliczkach, dano im ryż i pałeczki, a one nie miały żadnego pojęcia jak się nimi posługiwać. To było dla nich zupełnie nowe doświadczenie. Ojciec zawsze podkreślał, że Japończycy byli dla nich bardzo dobrzy i serdeczni. Dużo uwagi i czasu poświęcali małym dzieciom, wozili ich na wycieczki, pokazywali lokalne buddyjskie świątynie, w szkole uczyli podstaw języka japońskiego, elementarnej matematyki, nowych zabaw dziecięcych, piosenek, wierszyków. Po latach, gdy byłam małym dzieckiem, ojciec też uczył mnie liczyć do dziesięciu po japońsku. Śpiewał mi także japońskie piosenki dziecięce typu „moshi moshi kameio”. To były chyba rzeczywiście jedne z najbardziej niezwykłych i pięknych miesięcy jego życia, które tak silnie zapisały się w jego pamięci. Do końca życia. Opowiadał także, że był jednym z tych polskich dzieci głaskanych przez japońską cesarzową, która odwiedziła ich w ośrodku Czerwonego Krzyża w Tokio wiosną $1921 \mathrm{r} .{ }^{16}$

Kiedy dorastałam, w okresie wczesnego dzieciństwa, w naszym domu rodzinnym był taki stary stół z szufladą. Mój ojciec miał tam mapy: starą mapę Polski, mapę Japonii, mapę Stanów Zjednoczonych i atlas świata. On je często wyjmował, otwierał i pokazywał mi miasta, w których już wcześniej był, które znał, gdzie się urodził, gdzie jest Japonia, gdzie są Stany. Po wojnie, w naszym domu, kiedy wszyscy słuchali Radia Wolna Europa, ojciec zawsze czekał na wiadomości i informacje o Japonii. Niezależnie od roli Japonii podczas II wojny światowej, ojciec darzył Japończyków wielką sympatią, wierzył w lepszą przyszłość tego kraju, wierzył w dobrych ludzi. Był im bardzo wdzięczny za okazaną pomoc. On też bardzo kochał przyrodę, zawsze opowiadał o pięknych drzewach japońskich, o sadach wiśniowych, o bujnej wczesnej wiosennej zieleni, o tym jak to wszystko tam wtedy pięknie kwitło. To, co on wcześniej zobaczył w Japonii, to było dla niego zawsze takie najładniejsze, najlepsze i bardzo ważne.

\section{M.P.: Kiedy dzieci zostały przewiezione do Stanów Zjednoczonych?}

A.D.: Dzieci przypłynęły statkiem z Jokohamy do Seattle w czerwcu $1921 \mathrm{r}$. Ojciec wspominał, że zeszli ze statku na ląd dopiero po dwóch czy trzech dniach, bo odprawa imigracyjna zajęła im więcej czasu niż się spodziewali. W Seattle przywitała ich miejscowa Polonia ${ }^{17}$.

\footnotetext{
16 Cesarzowa Teimei, księżna Sadako Kujō (1884-1951), żona cesarza Taisho.

17 W Seattle przyjęciem dzieci zajmował się powołany w tym celu Komitet Przyjęcia Dzieci Syberyjskich, współpracujący m.in. z Towarzystwem Domu Polskiego. Obecnie w Domu Polskim zawieszona jest fotografia przedstawiająca grupę dzieci syberyjskich. W pomoc zaangażowany był również miejscowy oddział filantropijnej organizacji Rycerze Kolumba.
} 
Dzieci zostały przewiezione z portu do Domu Polskiego na obiad i od razu tego samego dnia zostały wysłane pociągiem do Chicago ${ }^{18}$. W tym mieście również przywitała je lokalna Polonia, po czym dzieci zostały rozesłane do internatów i sierocińców w kilku stanach ${ }^{19}$. Po raz kolejny moja rodzina została podzielona. Obie ciotki trafiły do Reading w Pensylwaniii ${ }^{20}$, a ojciec z grupą ok. tuzina innych chłopaków, do New Britain w stanie Connecticut ${ }^{21}$. Ojciec został zakwaterowany w ochronce przyklasztornej i tam chodził do szkoły początkowej. Ciotki, ze znacznie większą grupą dzieci, trafiły do internatu. Wychowawcy i nauczyciele próbowali zapoznać dzieci z życiem amerykańskim. Najważniejsze było to, że dali im możliwość uczenia się podstawowych przedmiotów. Starsze dzieci, które były w okolicach Chicago trafiły lepiej, bo były przygotowywane do zawodu. Ojciec jeszcze był chyba na to za mały, miał ciągle tylko 12 lat. W Stanach Zjednoczonych dzieci spędziły prawie 8 miesięcy. Ojciec całe życie był w stanie powiedzieć kilka podstawowych zdań po angielsku, niemniej jednak po upływie lat już nie pamiętał zbyt dobrze tych wyuczonych zwrotów. W styczniu 1922 r. wszystkie dzieci zostały zebrane w Nowym Jorku i statkiem wysłane do Polski ${ }^{22}$. Statek ten nazywał się Princess Matoyka. Kilka dni po wypłynięciu z portu w Nowym Jorku na statku wybuchł pożar. Po ugaszeniu pożaru statek musiał wracać do Nowego Jorku, do naprawy, która zajęła dobrych kilka dni. Po jej ukończeniu statek ponownie wypłynął w kierunku Hamburga i Bremy.

M.P.: Jak potoczyły się losy Pani ojca i ciotek po przyjeździe do Polski?

A.D.: Moja rodzina po powrocie do Polski trafiła do Poznania. Ponieważ moje ciotki były jednymi ze starszych dzieci syberyjskich tego transportu, od razu zostały skierowane do szkoły handlowej w tym mieście. W trakcie nauki mieszkały na pensji. O ciotce Felicji nie mam zbyt dużo informacji, a starsza ciotka Łucja Czesława po skończeniu kursów handlowych pracowała w księgarni Gebethnera i Wolffa w Poznaniu. Po krótkim czasie pracy w tym mieście, obie moje ciotki zdały egzamin na 3 kurs seminarium nauczycielskiego w Wejhero-

\footnotetext{
18 Chicago było siedzibą Wydziału Narodowego Polskiego. Decyzją jego władz kierownik Szkoły Przemysłowej dla Sierot w Niles pod Chicago, ks. Franciszek Rush zajmował się rejestracją wszystkich dzieci przybywających do USA. Zob. Sprawozdanie z konferencji odbytej 22 X 1920, MPA, WNP, sygn. 205.

19 Łącznie do Stanów Zjednoczonych przywieziono 369 dzieci. 28 lipca 1921 r., po przybyciu ostatniego transportu Wydział Narodowy utrzymywał 355 dzieci. Przebywały one w ośrodkach w Connecticut (New Britain), Illinois (Niles), Michigan (Detroit), Pensylwanii (Cambridge Springs, Emsworth, Conshohocken, Reading), Wisconsin (Milwaukee, Polonia, Manitowoc). Rozmieszczenie i koszt utrzymania Dzieci Syberyjskich według stanu z dnia 28 lipca 1921, MPA, WNP, sygn. 205.

20 Sierociniec św. Franciszka.

21 Sierociniec św. Marii.

22 W USA z różnych względów pozostało 57 dzieci, 2 już wcześniej odesłano do krewnych do Polski, Dzieci, które pozostaja i z jakich przyczyn, MPA, WNP, sygn. 205.
} 
wie, zamieszkały w internacie prowadzonym tam przez Józefa Jakóbkiewicza ${ }^{23}$. Wcześniej naukę w Wejherowie rozpoczęła starsza ciotka, a w następnym roku młodsza. Natomiast mój ojciec z trójką innych kolegów został wysłany do szkoły ogrodniczej w Koźminie koło Poznania, którą ukończył po 3 latach. Mam nawet dyplom ukończenia przez niego tej szkoły. Po zakończeniu edukacji ojciec dostał zatrudnienie w ogrodach miejskich w Katowicach, jednak po kilku latach pobytu na Śląsku w związku z redukcją etatów został zwolniony i wyjechał na Podlasie do rodziny.

M.P.: Jak długo przebywał w sowieckich więzieniach Pani dziadek?

A.D.: Dziadek przebywał w więzieniu kilka lat. Po wojnie polsko-sowieckiej, rząd polski rozpoczął pertraktacje z sowietami dotyczące wymiany więźniów. W ramach jednej z wymian, dziadek jako więzień polityczny powrócił do Polski. Trudno mi wyjaśnić, jak to się stało, bo nie znam szczegółów. Niemniej, tak jak opowiadał później mój ojciec, dziadek pod konwojem dotarł do granicy w Stołpcach gdzieś w 1925 r. lub nawet już na początku 1926 r. ${ }^{24}$ Dziadek był bardzo szczęśliwy, przekraczając granicę ucałował polską ziemię. Mając prawie pięćdziesiąt lat, po ponad dwudziestu latach pracy na Syberii, na którą wyjechał z perspektywą poprawy życia, wrócił do Polski „bez niczego, bez żadnych pieniędzy. Tak jak wyjechał, tak wrócił”, jak wspominał ojciec. Skierował się w rodzinne strony, na Podlasie, tam skąd on i babcia pochodzili.

\section{M.P.: Kiedy do Polski powróciła Pani babcia?}

A.D.: Nie znam szczegółów, kiedy i w jaki sposób babci udało się powrócić z najmłodszym synem Stanisławem, wtedy już 12 lub 13-letnim chłopcem do kraju. Ale wróciła w rodzinne strony, do bliskich. Niestety, tragiczne warunki życia na Syberii odbiły się na jej zdrowiu, schorowana poruszała się już na wózku inwalidzkim. Zmarła w $1936 \mathrm{r}$.

M.P.: Powrót po wielu latach, po traumatycznych doświadczeniach był z pewnością trudny. Jak rodzina Kuleszów odnalazła się w nowej rzeczywistości?

${ }^{23}$ Zakład Wychowawczy Dzieci Syberyjskich w Wejherowie. Mieszkała w nim i uczyła się część dzieci syberyjskich. Funkcjonował w latach 1923-1929. Jakóbkiewicz był jego kierownikiem od chwili jego założenia, W. Theiss, op. cit., rozdz. VI.

24 Aleksander Kulesza znajdował się na „liście 208”, skupiającej Polaków więźniów politycznych w Związku Sowieckim przeznaczonych do wymiany za istotnych dla Moskwy więźniów polskich. Wymiana przeprowadzona w nocy z 31 I na 1 II 1925, jednak go nie objęła, na co wskazuje jego obecność wśród więźniów przebywających na Łubiance. Do Polski powrócił w ramach jednej z kolejnych wymian, trudno jednak ustalić, której dokładnie. Zob. Personalja osób przeznaczonych przez Delegację Polską...; Lista osób przeznaczonych do wymiany skoncentrowanych $w$ więzieniu wewnętrznym na Eubiance, 4 II 1925, [w:] Wymiana więźniów politycznych..., s. 206. Szerzej na temat wymiany więźniów politycznych W. Materski, Pobocza dyplomacji: wymiana więźniów politycznych pomiędzy II Rzeczapospolita a Sowietami w okresie międzywojennym, Warszawa 2002. 
A.D.: Jak już mówiłam, gdy mój ojciec utracił pracę w Katowicach, podążył w rodzinne strony na Podlasie. Moi dziadkowie wynajmowali wówczas dom w Sokołach, między Łapami a Wysokiem Mazowieckiem. Tam mój ojciec wraz dziadkiem i młodszym bratem, ponieważ miał już wyuczony zawód, otworzyli własny biznes, a mianowicie założyli szkółkę sadzonek drzew. Pracowali ciężko, dzierżawili sady, wynajmowali gospodarstwa i z czasem dorobili się jakiegoś tam zasobu finansowego. Po jakimś czasie za pieniądze otrzymane w wyniku sprzedaży szkółek drzew i za zgromadzone oszczędności kupili dom i działkę w Łapach, gdzie mieszkali już do końca życia.

M.P.: Jak Pani krewni wspominali życie w Rosji?

A.D.: O swoim życiu na Syberii opowiadali niechętnie i niezbyt często, zwłaszcza na początku. Zarówno obie ciotki, jak i mój ojciec o swojej przeszłości nie opowiadali zbyt chętnie, także dlatego, że - jak gdzieś wcześniej słyszałam - te dzieci, które trafiły do Wejherowa były nazywane „ruskimi”. Pewnie dlatego, że przybyły z odległej Syberii, z Rosji, ich język polski nie zawsze był poprawny, albo od czasu do czasu słychać było rosyjski akcent. Niemniej jednak to były bardzo patriotyczne polskie dzieci, ale w rezultacie spędzenia dzieciństwa na Syberii trochę ,inne”. Dzieci na Syberii chodziły do szkoły rosyjskiej, a więc rosyjski był ich pierwszym językiem. Polskiego uczyły się w domu rodzinnym i w Domu Polskim. Moja rodzina nigdy nie chciała być tymi „ruskimi”. To byli Polacy, dla nich najważniejsza była ich polskość. Swój rosyjski epizod moi krewni może nie tyle ukrywali, ile nie chcieli się nim afiszować ani specjalnie do tego wracać. I może dlatego nie chcieli też, żeby ktokolwiek słyszał ich mówiących po rosyjsku. Na przykład w naszym domu, jak ojciec czasami gotował, to przygotowywał nie naleśniki, ale jak się u nas mówiło bliny. Były więc w użyciu słowa rosyjskie, ale sporadyczne i rzadko powtarzane. Mój ojciec nie darzył Rosjan zbyt wielką sympatią, był wobec nich nieufny, bo to, przez co tam przeszedł i co tam przeżył on i jego rodzina, po prostu ukształtowało niekoniecznie pozytywny ich obraz. Nawet kiedy uczyłam się w szkole średniej języka rosyjskiego ojciec nie chciał mi nigdy pomagać, a to przecież był język jego dzieciństwa, który tak dobrze znał. Nigdy mnie nie mobilizował do nauki tego języka. „Rosyjski? Wszystko tylko nie to. To ci niepotrzebne" jak mawiał. I tak rosyjskiego dobrze nigdy się nie nauczyłam, a szkoda. Natomiast wszyscy moi krewni opowiadali bardzo pozytywnie o indywidualnych mieszkańcach Syberii, o wielu życzliwych Rosjankach, które pomogły babci przeżyć zawieruchę wojenną tamtych czasów.

M.P.: Czy Pani dziadek miał taki sam stosunek wobec Rosji?

A.D.: Generalnie tak, ale zapamiętałam również jego zamiłowanie do literatury, także rosyjskiej. Gdy był już starszym człowiekiem, ponadosiemdziesięcioletnim i nie mógł już pracować fizycznie, wtedy częściej zajmował się mną. Chodził ze mną na spacery. Pamiętam, jak prowadził mnie za rękę, recytował 
wiersze Puszkina, Mickiewicza, Słowackiego, po polsku i po rosyjsku. To jest ciągle dla mnie niesamowite, cudowne wspomnienie mego dzieciństwa. Ja czasem teraz myślę, że wybrałam polonistykę jako kierunek moich studiów tylko dlatego, że to właśnie dziadek zaszczepił u mnie te zainteresowania i szacunek dla literatury. Nieprawdopodobna była jego pamięć i znajomość literatury, zarówno polskiej jak i rosyjskiej. I te liczne fragmenty wierszy recytowane z pamięci.

M.P.: Jak Pani ojciec zapamiętał Stany Zjednoczone?

A.D.: Mój ojciec zawsze bardzo pozytywnie i z sympatią opowiadał o Stanach Zjednoczonych. Mówił, że pobyt w Stanach był innym doświadczeniem niż pobyt $\mathrm{w}$ Japonii. W wieku 12 lat po raz pierwszy w życiu został sam, rodzice ciągle byli na Syberii, siostry w Pensylwanii, a on razem z mała grupą chłopców w stanie Connecticut. Zadziwiające, jak samotne dzieci zostawione w świecie dorosłych szybko dojrzewają. Pamiętam też, jak ojciec mi opowiadał, że nawet chciał zostać w Stanach, ale starsza ciotka - z racji wieku opiekunka rodzeństwa - powiedziała, że „nawet nie ma o czym mówić. Rodzice wysłali nas do Polski, a zatem musimy wracać do Polski, do rodziny".

$\mathrm{Na}$ początku lat 80. mój 75-letni wtedy ojciec odwiedził nas w Stanach, w Princeton, w New Jersey. Był u nas dwa miesiące. Często wspominał swoje dzieciństwo, swój pierwszy pobyt w Stanach. I to właśnie wtedy dużo opowiadał o Ameryce jego dzieciństwa. Był też taki ciekawy ówczesnej Ameryki. Czasem zastanawiał się, jak wyglądałoby jego życie, gdyby w niej został. Bardzo się cieszył bawiąc się z jego pierwszym wnukiem urodzonym w Stanach.

M.P.: Czy Pani krewni utrzymywali kontakt $z$ innymi dziećmi ewakuowanymi z Dalekiego Wschodu?

A.D.: Nie wiem. Pamiętam, że ojciec czasem mówił o innych dzieciach syberyjskich, o swoich kolegach ze szkoły ogrodniczej (zachowało się też kilka szkolnych zdjęć). Pamiętam też nazwisko pani Wróblewskiej. To jedyne nazwisko, które zapamiętałam. Ponieważ mój ojciec nigdy nie trafił do Wejherowa, tak jak większość dzieci syberyjskich, które wróciły do Polski, prawdopodobnie dlatego jego kontakt z grupą syberyjską był raczej sporadyczny. Jego siostry zaczęły naukę w seminarium nauczycielskim dopiero po krótkim pobycie w Poznaniu. Ojciec nigdy nie był w Wejherowie, więc prawdopodobnie dlatego intensywnych kontaktów z resztą dzieci syberyjskich nie było. Moja rodzina też mieszkała trochę dalej od głównych zgrupowań owych „sybiraków”, takich jak Warszawa czy okolice Poznania. Dopiero po śmierci najstarszej ciotki dowiedziałam się o listach pisanych przez nią do Józefa Jakóbkiewicza, głównego opiekuna i wychowawcy wszystkich dzieci syberyjskich, a także znalazłam jego listy pisane do ciotki Czesławy Łucji. Bardzo serdecznie opisywał radość odnalezienia się po kataklizmie II wojny światowej, o swoim małżeństwie z jedną ze swoich wychowanek, o swoich dzieciach, o tym, że wojna zastała go w Senegalu, o swojej 
pracy w szpitalu w Grenoble, powojennym powrocie do Polski i pracy w szpitalu w Cieplicach Śląskich ${ }^{25}$.

M.P.: Pani Anno, podsumowując można powiedzieć, że w pewnym sensie historia Pani rodziny zatoczyła koło. Pani ojciec chciał zostać w USA, ale nie mógł, podporządkował się woli starszej siostry. Po latach to Pani zamieszkała w tym państwie, które już od wielu lat jest dla Pani drugą ojczyzną. Przyglądając się burzliwym i niezwykłym losom rodziny Kuleszów przychodzi mi na myśl refleksja że może jej członkowie przekazują sobie z pokolenia na pokolenie jakiś ,gen emigracyjny" - swego rodzaju wewnętrzny impuls, skłaniający do poszukiwania właściwego dla siebie miejsca.

A.D.: Być może ma Pan rację, ale współczesny świat tak się zmienił, a odległości - dzięki technice tak się „,zmniejszyły”, że żyć i czuć się u siebie można praktycznie wszędzie. Najważniejsze, żeby być dobrym i uczciwym człowiekiem, rzetelnie pracować, szanować innych ludzi, pielęgnować swoją tradycję. Moje pokolenie jest chyba pierwszym powojennym pokoleniem, które nie doświadczyło tragedii wojny i rewolucji. Porównując życie moich przodków i moje, myślę, że teraz jest chyba najlepiej. Możemy marzyć, podróżować, uczyć się i budować wolną przyszłość. Mam nadzieję, że nasze dzieci też będą mogły żyć w wolnym kraju, w wolnym i bezpiecznym świecie. Wolność i pokój to takie niesłychanie ważne i istotne wartości, ale bardzo delikatne, bo tak łatwo można je stracić, a odbudować będzie bardzo trudno i ciężkim kosztem.

M.P.: Dziękuję za rozmowę

A.D.: Dziękuję.

25 Wojna zastała Jakóbkiewicza we francuskim Senegalu, gdzie jako specjalista od chorób tropikalnych, zajmował się kształceniem lekarzy. Następnie przeniósł się do Francji, gdzie przebywał do 1946 r. pracując dla Czerwonego Krzyża. Po powrocie do Polski został skierowany do pracy w uzdrowisku w Cieplicach Śląskich. Zmarł w 1953 r. W. Theiss, op. cit., s. 49-50. 